\title{
V8 - Desenvolvimento de um processo de purificação do vírus da Febre Amarela para aplicação na produção de uma vacina inativada
}

Tânia Pinheiro Pato Cunha ${ }^{1 *}$; Marta Cristina de OliveiraSouza ${ }^{1}$; Luciane Pinto Gaspar $^{1}$; Elena Caride ${ }^{1}$; Marcos da Silva Freire ${ }^{1}$; Leda dos Reis Castilho ${ }^{1}$.

\section{1 - Bio-Manguinhos/FIOCRUZ}

\section{Introdução:}

A febre amarela é uma doença infecciosa viral aguda, não contagiosa, com alto índice de morbidade e letalidade. No Brasil, é endêmica na região amazônica, com surtos esporádicos. A sua ocorrência em reservatório silvestre torna virtualmente impossível sua erradicação, sendo a vacinação o modo mais eficiente de evitar e controlar a doença. Uma vacina atenuada, produzida utilizando-se ovos embrionados, está disponível desde 1937. Apesar de altamente eficaz e segura, relatos de graves eventos adversos estimularam o desenvolvimento de uma vacina inativada. Bio-Manguinhos produz a vacina atenuada e, nos últimos anos, estabeleceu uma metodologia de produção do vírus em biorreatores utilizando células Vero, para posterior purificação e inativação. Pretende-se, assim, evitar a incidência de eventos adversos graves e possibilitar a imunização de indivíduos com alergia a proteínas do ovo, imunossuprimidos, mulheres grávidas, lactentes e crianças menores de nove meses.

\section{Objetivo:}

Este trabalho teve como objetivo desenvolver um processo de purificação da suspensão viral amarílica produzida em células Vero, que forneça o vírus com os atributos de pureza atualmente requeridos pelas agências regulatórias para vacinas de uso humano e que resulte em uma tecnologia com viabilidade técnica, operacional e econômica para ser aplicada na manufatura da vacina inativada.

\section{Metodologia:}

Inicialmente, foi estudado o uso de membranas adsortivas de troca aniônica (Sartobind ${ }^{\oplus}$ Q) para a etapa de captura do vírus a partir de sobrenadante de cultivo celular. Posteriormente, para reduzir os níveis de proteínas da célula hospedeira (HCP), uma segunda etapa (polimento) foi investigada, utilizan- 
do-se a cromatografia multimodal (CaptoTMCore 700). O produto purificado foi quantificado por titulação viral e ELISA e caracterizado por SDS-PAGE e ensaios de Western blot (WB) anti-proteína E e anti-HCP.

\section{Resultados:}

O processo desenvolvido resultou em um rendimento global de $52,7 \%$, com HCP residual de $345 \pm 25$ ppm (0,04 \pm 0,01\%) e 1,17 $\pm 0,35$ ng de DNA/dose, em acordo com o preconizado pela Organização Mundial de Saúde (< 10 ng/ dose). Para este cálculo, foi considerada a maior dose investigada em ensaios em camundongo. A análise eletroforética (SDS-PAGE) da amostra purificada apresentou uma banda com massa molar de $56 \mathrm{kDa}$, compatível com a proteína do envelope do vírus (E) e correspondendo a 96,7\% das proteínas identificadas. $\mathrm{O}$ WB anti-proteína $\mathrm{E}$ revelou uma única banda, que confirmou a identidade da amostra. Nenhuma banda foi revelada no WB anti-HCP, confirmando os baixos níveis de HCP quantificados.

\section{Conclusão:}

A metodologia desenvolvida atende a quatro dos principais critérios utilizados para a definição de um processo de purificação de partículas virais: (i) capacidade de processamento de grandes volumes; (ii) preservação da estabilidade viral; (iii) facilidade de ampliação de escala e (iv) produto dentro das especificações para fins vacinais. Sendo assim, é promissora sua utilização em processos industriais que visem à obtenção de uma vacina amarílica inativada.

Palavras-Chave: Febre Amarela; Purificação de partículas virais; Vacina inativada 